\title{
DIAGNOSIS OF CANINE LEPTOSPIROSIS USING AN IMMUNOMAGNETIC SEPARATION-PCR METHOD
}

\section{Leonardo Garcia Monte ${ }^{1,2}$, Sérgio Jorge ${ }^{3}$, João Paulo Mesquita Luiz ${ }^{2}$, Francine Sinnott ${ }^{2}$, Fabiana Kömmling Seixas ${ }^{3}$, José Antonio Guimarães Aleixo ${ }^{1}$, Luis Ernesto Samartino ${ }^{4}$, Fabricio Rochedo Conceição ${ }^{1}$, Cláudia Pinho Hartleben ${ }^{2 *}$}

${ }^{1}$ Laboratório de Imunologia Aplicada, Núcleo de Biotecnologia, Centro de Desenvolvimento Tecnológico, Universidade Federal de Pelotas, Pelotas, RS, Brasil; ${ }^{2}$ Laboratório de Imunodiagnóstico, Núcleo de Biotecnologia, Centro de Desenvolvimento

Tecnológico, Universidade Federal de Pelotas, Pelotas, RS, Brasil; ${ }^{3}$ Laboratório de Biologia Molecular, Núcleo de Biotecnologia, Centro de Desenvolvimento Tecnológico, Universidade Federal de Pelotas, Pelotas, RS, Brasil; ${ }^{4}$ Instituto Nacional de Tecnologia Agropecuária (INTA) Centro de Ciências Veterinárias y Agronômicas (CICVyA), Instituto de Patobiologia, Buenos Aires, Argentina.

Submitted: August 07, 2011; Returned to authors for corrections: September 25, 2011; Approved: June 07, 2012.

\begin{abstract}
Diagnosis of leptospirosis by PCR is hampered due to the presence of substances on biological fluids. Here, we report an immunomagnetic separation step prior to PCR which improved the detection of Leptospira spp. in blood and urine samples from dogs. It resulted in a significant improvement on sensitivity for diagnosis of canine leptospirosis.
\end{abstract}

Key words: Canine leptospirosis, IMS-PCR, LipL32.

Leptospirosis is a zoonosis of ubiquitous distribution, caused by infection with pathogenic Leptospira spp., which occurs in many animal species and humans (1). Dogs may be exposed to leptospires in the environment by contact with urine of an infected host, contaminated water or moist soil, where the bacteria may survive for several months $(5,12)$. In the last years, several assays have been proposed for confirmation of canine leptospirosis, including serology, polymerase chain reaction (PCR), fluorescent antibody testing of urine or tissue samples, or organism isolation (8).

The recommended laboratory diagnostic test, microscopic agglutination test (MAT), is based on detection of antibodies against Leptospira spp. in dog sera; however, pathogenspecific antibodies may remain in the blood stream for a long period, even after recovering from disease. Besides serology, demonstration of leptospires by culture of blood, tissues or urine is definitive; it also identifies the infecting leptospire (7).

PCR assay is highly sensitive, but the presence of PCR inhibitory substances on biological fluids can prevent amplification, resulting in false negative (10). Recent studies report the immunomagnetic separation (IMS) technique prior to PCR assay as an approach to reduce the effect of inhibitory substances present in biological fluids and food samples (2, 3, $4,6,7,9,14,15)$. For diagnosis of leptospirosis, the IMS-PCR approach was reported to detect Leptospira spp. in bovine urine (15) and in human biological fluids (6). In order to improve PCR sensitivity and specificity, we developed a novel IMSPCR approach by using both magnetic beads in house coated

*Corresponding Author. Mailing address: Núcleo de Biotecnologia, Centro de Desenvolvimento Tecnológico, Universidade Federal de Pelotas, Capão do Leão, 96010-900, RS, Brazil.; Tel.: +55 5332757583 Fax: +55 53 32757551.; E-mail: claudia.hartleben@pq.cnpq.br 
with a monoclonal antibody $(\mathrm{mAb})$ and specific PCR primers for pathogenic Leptospira spp. $(6,9)$. Blood and urine samples were obtained from dogs suspected of having leptospirosis $(n=5)$ at the Veterinary Hospital/ Universidade Federal de Pelotas, Brazil. Blood samples were centrifuged at 2,000 x $g$ for $5 \mathrm{~min}$, the supernatant was collected, and one drop was observed under microscope to investigate the presence of spirochetes by darkfield microscopy (DFM) on an Olympus BX 51 microscope. Control samples were obtained from healthy dogs $(n=5)$ negative by MAT. The MAT was performed according to Faine et al. (5), using reference strains of 19 different leptospiral serovars. Reciprocal agglutination titres of greater than or equal to 1:100 were considered positive reactions.

For PCR assay, blood sera and urine samples were centrifuged at $15,000 \times \mathrm{g}$ for $10 \mathrm{~min}$. The cells were washed with sterile $0.01 \mathrm{M}$ phosphate-buffered saline (PBS, $\mathrm{pH} 7.2$ ) and the DNA was extracted by heating at $95{ }^{\circ} \mathrm{C}$ for $15 \mathrm{~min}$ in $50 \mu \mathrm{L}$ of lysis solution $(1: 1$ of $0.125 \%$ SDS and $0.05 \mathrm{M}$ $\mathrm{NaOH}$ ). In experiments in which lysis followed IMS, $20 \mu \mathrm{L}$ of the lysis solution were directly added to immune separated products in microtubes and then heated at $95{ }^{\circ} \mathrm{C}$ for $15 \mathrm{~min}$. Primers lipL32 F: 5' CGCTTGTGGTGCTTTCGGTGGT 3' and lipL32 R: 5' CTCACCGATTTCGCCTGTTGGG 3' were used, resulting in a $264 \mathrm{bp}$ amplicon of the lipl32 coding region (9). Amplification was carried out in a Peltier Thermal Cycler PTC-100® (Bio-Rad) with 1 cycle at $94{ }^{\circ} \mathrm{C}$ for $5 \mathrm{~min}, 35$ cycles at $94{ }^{\circ} \mathrm{C}$ for $1 \mathrm{~min}, 55^{\circ} \mathrm{C}$ for $1 \mathrm{~min}, 72^{\circ} \mathrm{C}$ for $1 \mathrm{~min}$, followed by an extension for $7 \mathrm{~min}$ at $72{ }^{\circ} \mathrm{C}$ at the end of the final cycle. Aliquots were analyzed by electrophoresis in $1 \%$ agarose gel with ethidium bromide and visualized under UV transillumination. A specific PCR internal amplification control (IAC) was used in all assays, which consists of a DNA fragment containing 501 bp not related to Leptospira spp., flanked by target sequences of lipL32 primers (6). The IAC concentration was estimated spectrophotometrically at $260 \mathrm{~nm}$ and the optimal concentration for use in the lipL32 PCR was determined by titration, and the lowest reproducible concentration was determined using decimal dilutions of IAC (50 to $0.05 \mathrm{pg}$ ) as template DNA in a PCR with lipL32 primers. PCR and IAC-PCR were performed using a single pair of lipL32 specific primers.

Determination of the minimal concentration of DNA and number of leptospiral cells required to result in amplification of the lipL32 gene sequence by PCR was carried out according to Fernandes et al. (6). Briefly, genomic DNA from $L$. interrogans was diluted with sterile $10 \mathrm{mM}$ Tris- $\mathrm{HCl}, 1 \mathrm{mM}$ EDTA (TE, $\mathrm{pH} 8.0$ ) to concentrations ranging from 20 to 1 $\mathrm{pg} / \mu \mathrm{L}$, and pellets from control samples artificially contaminated with Leptospira interrogans serovar Canicola strain Hond Utrecht IV at concentrations ranging from $10^{8}$ to $10^{0}$ cells per $\mathrm{mL}$. Then, the pellets from each DNA concentration and bacterial dilution were washed with PBS and suspended in $50 \mu \mathrm{L}$ of lysis buffer for DNA extraction. DNA extracted from saprophytic L. biflexa serovar patoc Patoc I or $E$. coli were used as negative controls. These experiments were repeated three times.

The IMS-PCR was performed with protein A-magnetic beads (Bangs Laboratories Inc, Fishers, IN, USA) adsorbed with a mAb against leptospira LipL32 protein according to the manufacturer's instructions. The mAb used in this work is specific to pathogenic leptospires (6). Briefly, $10 \mu \mathrm{L}$ of mAbcoated beads were added to clinical and control samples. The immunocapture complex was washed three times, suspended in DNA extraction buffer, boiled and used on PCR assay. To perform the experiments, an immunomagnetic separator MPC$\mathrm{S}$ (Invitrogen, CA, USA) was used.

All 5 dog serum samples were MAT positive with titers that varied from 100 to 3200 . The antibodies most frequently found in the MAT recognized serovars Canicola CCZ463 (5/5), Canicola Hond Utrecht IV (4/5), Icterohaemorrhagiae (4/5), Copenhageni (4/5), Ballum (3/5) and Grippotyphosa (3/5). The highest agglutination titers corresponded to serovars Canicola CCZ463 and Canicola Hond Utrecht IV. No agglutination was 
observed in sera from healthy dogs. Conventional PCR assay was able to detect 2 pg per $25 \mu \mathrm{L}$ of pure genomic Leptospira DNA and $10^{3}$ cells per $\mathrm{mL}^{-1}$ either in artificially contaminated canine serum or urine samples (data not shown). When IMS was applied on artificially contaminated samples prior to PCR the detection limit decreased to $10^{2}$ cells $\mathrm{mL}^{-1}$ (Fig. 1A). No amplification was observed after IMS-PCR performed with saprophytic strains or $E$. coli, or when non-sensitized beads were used for IMS with pathogenic strains (data not shown). PCR performed without previous IMS treatment amplified lipL32 gene sequence from four urine and one serum samples (data not shown). The IMS-PCR performed with canine leptospirosis clinical samples was able to amplify lipL32 sequence gene in all urine and in two out of five serum samples tested. These results are demonstrated in Fig. 1B. The IMS-PCR approach enhanced the PCR method since the conventional PCR failed to detect one positive sample.

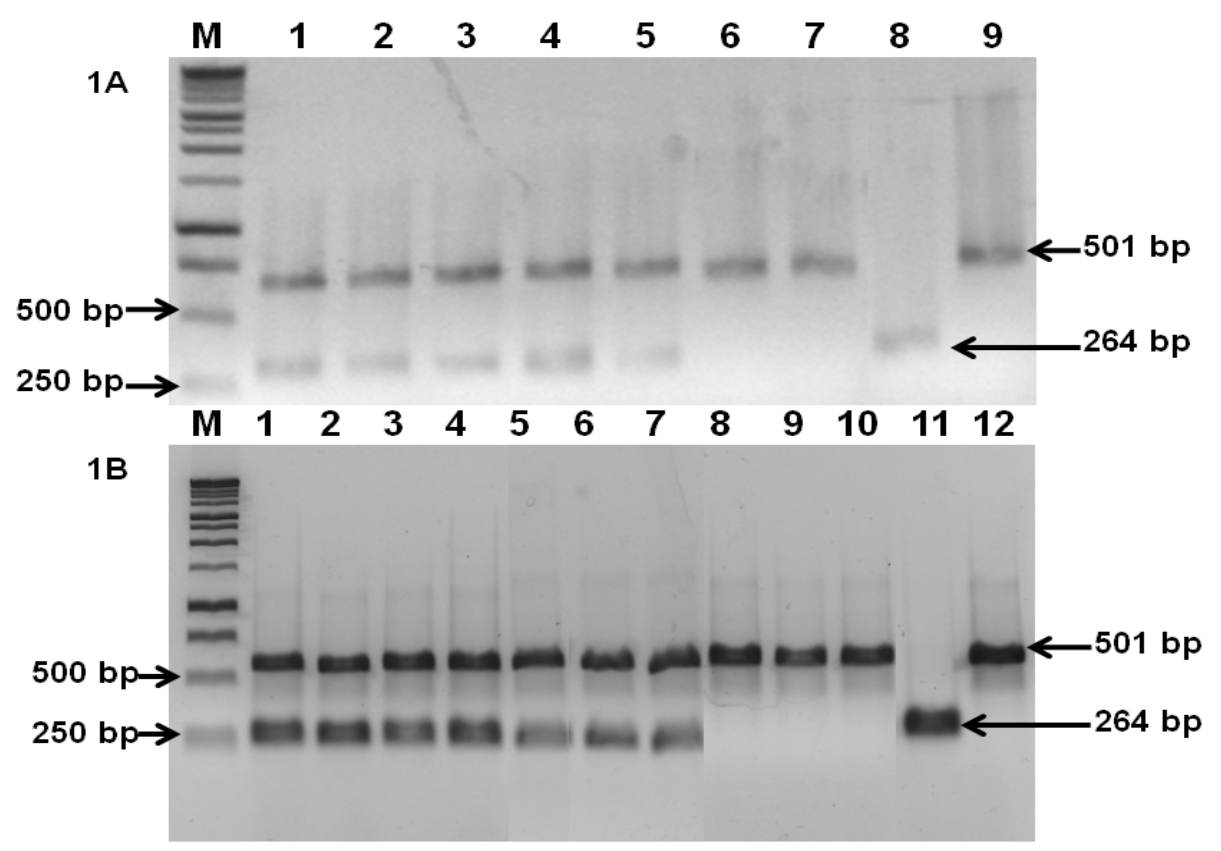

Figure 1. Agarose electrophoresis of IMS-PCR from artificially contaminated and clinical fluid samples in presence of 0.5 pg of IAC. Panel A, detection limit of L. interrogans serovar Canicola strain Hond Utrecht IV in artificially contaminated dog urine samples: M, 1 kb DNA Ladder; Lanes $1-7,10^{6}, 10^{5}, 10^{4}, 10^{3}, 10^{2}, 10^{1}, 10^{0}$ leptospires per mL, respectively; lane 8 , DNA only, lane 9, IAC only. Panel B, detection of Leptospira spp. amplified from dog clinical samples. M, 1kb DNA Ladder; lane 1-5 (urine) and 6-10 (blood), respectively. Lane 11 DNA only; Lane 12 IAC only.

Canine leptopirosis has a variable clinical presentation but, as a consensus, it results in leptospira renal scarring (5). The recommended diagnostic test has to be done by testing paired acute and convalescent sera to confirm the diagnosis, which is helpful in unvaccinated dogs, but hard to interpret in vaccinated ones (6). The antibodies detection methods are not useful before seven days after leptospira infection and the standard method, MAT; require paired samples to detect seroconversion (5). For those reasons, antigen detection tests offer potential advantage over tests based on antibody detection both for early diagnosis and identification of renal carrier status (5). Therefore, research focused on highly sensitive and specific routine tests for leptospira detection in blood and urine samples led to development of several molecular methods for 
diagnosis of leptospirosis $(4,6,9,14)$. However, the sensitivity and kinetics of PCR diagnostic tests may be dramatically reduced when applied directly to biological samples, such as urine and serum samples (11). The presence of inhibitor molecules and heterogeneous bacteria in the samples can affect PCR performance (13).

Here, we demonstrated that the IMS step can be useful for concentrating leptospires in clinical samples to allow detection by PCR and for reducing inhibitory substances which led to increase in sensitivity. Although the IMS-PCR was able to detect leptospires in only two out of five serum samples tested, high agglutination antibodies titers were found in those sera and no spirochetes were visualized under DFM suggesting absence of leptospiremia in those animals. The use of a sensitive leptospira detection method such as the IMS-PCR, may constitute an important tool for identification of leptospira renal scarring.

In conclusion, this study demonstrated that IMS using an extensively characterized $\mathrm{mAb}$ against LipL32, a surface exposed outer membrane protein present in all pathogenic leptospires, is efficient in capturing pathogenic leptospiral cells. In addition, the IMS coupled to PCR has the potential to improve sensitivity and specificity of a diagnostic test for leptospirosis. The same approach may be useful for detection of other pathogens.

\section{ACKNOWLEDGEMENTS}

This work was supported by FAPERGS (09/0374-8ARD) and CNPq (403037/2008-5). We are grateful to Dr. C. S. Brod from Center for Zoonosis Control-UFPel for providing Leptospira serovars and Veterinary Hospital, Universidade Federal de Pelotas, Brazil, for providing clinical samples. LGM was recipient of a scholarship from CAPES, Ministry of Education, Brazil.

\section{REFERENCES}

1. Adler, B.; Moctezuma A.P. (2010). Leptospira and leptospirosis. Vet. Microbiol. 140, 287-296.

2. Coklin T.; Farber, J.M.; Parrington, L.J.; Kingombe, C.I.B.; Ross, W.H.;
Dixon, B.R. (2011). Immunomagnetic separation significantly improves the sensitivity of polymerase chain reaction in detecting Giardia duodenalis and Cryptosporidium spp. in dairy cattle. J. Vet. Diagn. Invest. 23, 260-267.

3. Corona-Barrera, E.; Smith, D.G.; La, T. (2004). Immunomagnetic separation of the intestinal spirochaetes Brachyspira pilosicoli and Brachyspira hyodysenteriae from porcine faeces. J. Med. Microbiol. 53, 301-307.

4. Brown, P.D; Gravekamp, C.; Carrington, D.G.; Kemp, H.V.; Hartskeerl, R.A.; Edwards, C.N.; Everard, C.O.R.; Terpstra, W.J.; Levett, P.N.1. (1995). Evaluation of the polymerase chain reaction for early diagnosis of leptospirosis. J. Med. Microbiol. 43, 110-114.

5. Faine, S.; Adler, B.; Bolin, C.; Perolat, P. Leptospira and Leptospirosis, 2nd Edna MedSci: Melbourne. Austrália, 1999, 272.

6. Fernandes, C.H.; Seixas, F.K.; Coutinho, M.L.; Vasconcellos, F.A.; Moreira, A.N.; Conceição, F.R.; Dellagostin, A.O.; Aleixo, J.A. (2008). An immunomagnetic separation-PCR method for detection of pathogenic Leptospira in biological fluids. Hybridoma. 27, 381-386.

7. Gray, K.M.; Bhunia, A.K. (2005). Specific detection of cytopathogenic Listeria monocytogenes using a two-step method of immunoseparation and cytotoxicity analysis. J. Microbiol. Met. 60, 259-268.

8. Greene, C.E.; Sykes, J.E.; Brown, C.A. (2006). Leptospirosis. In: Greene $\mathrm{CE}$, ed. infectious diseases of the dog and cat, 3 ed. St Louis, MO: Saunders Elsevier: 402-417.

9. Jouglard, S.D.; Simionatto, S.; Seixas, F.K.; Nassi, F.L.; Dellagostin, O.A. (2006). Nested polymerase chain reaction for detection of pathogenic leptospires. Can. J. Microbiol. 52, 747-52.

10. Lantz, P.G.; Al-Soud, A.W.; Knutsson, R.1. (2000). Biotechnical use of the polymerase chain reaction for microbiological analysis of biological samples. Biotechnol. Annu. Rev. 5, 87-130.

11. Radström, P.; Knutsson, R.; Wolffs, P.; Lövenklev, M.; Löfström, C. (2004). Pre-PCR processing strategies to generate PCR-compatible samples. Mol. Biotechnol. 26 133-146.

12. Raghavana, R.; Brenner, K.; Higginsc, J.; Merwe, D.V. (2011). Evaluations of land cover risk factors for canine leptospirosis: 94 cases (2002-2009). Prevent. Vet. Med. 101, 241-249.

13. Rosenstraus, M.; Wang, Z.; Chang, S.Y.; De Bonville, D.; Spadoro, J.P. (1998). An internal control for routine diagnostic PCR: design, properties, and effect on clinical performance. J. Clin. Microbiol. 36, 191-197.

14. Taban, B.M.; Ben, U.; Aytac, S.A. (2009). Rapid detection of Salmonella in milk by combined immunomagnetic separation-polymerase chain reaction assay. J. Dairy. Sci. 92, 2382-2388.

15. Yan, K.T.; Ellis, W.A.; Montgomery, J.M.; Mackie, D.P.; McDowell SW. (1998). Development of an immunomagnetic antigen capture system for detecting leptospires in bovine urine. Res. Vet. Sci. 64, 119124. 